\title{
Distinct Hemodynamic and Gastric Effects of Human CGRP I and II in Man
}

\author{
CHRISTOPH BEGLINGER,* WALTER BORN, $\dagger$ REINER MÜNCH, \\ JEAN-PIERRE GUTZWILLER, ${ }^{*}$ KURT JÄGER $\uparrow$ AND JAN A. FISCHER $\dagger^{1}$ \\ *Division of Gastroenterology, ๆDivision of Angiology, Department of Research \\ University of Basel Hospital, 4031 Basel, Switzerland \\ †Research Laboratory for Calcium Metabolism, Departments of Orthopedic Surgery and Medicine \\ University of Zurich, Forchstrasse 340, 8008 Zurich, Switzerland \\ $\ddagger$ Division of Gastroenterology, Department of Medicine, University of Zurich, 8091 Zurich, Switzerland \\ \$Institute of Physiology, University of Zurich, 8057 Zurich, Switzerland
}

Received 22 May 1991

\begin{abstract}
BEGLINGER, C., W. BORN, R. MÜNCH, A. KURTZ, J.-P. GUTZWILLER, K. JÄGER AND J. A. FISCHER. Distinct hemodynamic and gastric effects of human CGRP I and II in man. PEPTIDES 12(6) 1347-1351, 1991. - The human calcitonin gene-related peptides I and II (or $\alpha$ and $\beta$ ) (CGRP I and II) are encoded by two different genes, but they have 34 of the 37 amino acid residues in common. Human CGRP I more potently stimulated blood flow through the skin and carotid artery $(p<0.01)$, and the heart rate $(p<0.05)$, and plasma renin activity and aldosterone secretion than human CGRP II $(p<0.02)$. Inhibition of pentagastrin-stimulated gastric acid output, on the other hand, was only obtained with CGRP II. The separate effects of human CGRP I and $I$ on the cardiovascular and gastric systems are presumably mediated by different receptors or receptor pathways recognized by the two closely related neuropeptides.
\end{abstract}

Aldosterone Calcitonin gene-related peptide Gastric acid secretion Renin activity Vasodilatation

HUMAN and rat calcitonin gene-related peptides I and II (or $\alpha$ and $\beta$ ) (CGRP I and II) differ in only 3 and 1 of the 37 amino acid residues, respectively $(1,31)$. They are products of two separate genes. In man, the two genes are located on the same chromosome 11 and may have arisen by gene duplication (31). The relative expression of human CGRP I and II at the level of mRNA and mature peptides varies in different tissues $(6,15$, $28,34,35)$. CGRP exerts profound effects on the cardiovascular system of man and experimental animals, which include vasodilatation, positive chronotropic and ionotropic actions on the heart, and stimulation of plasma renin activity $(5,9-11,20,32)$. The latter effect represents a counterregulatory mechanism to the hypotension evoked by CGRP, but CGRP also directly stimulated the release of renin from juxtaglomerular cells (20).

CGRP, moreover, inhibits gastric acid secretion with unchanged mucosal blood flow $(19,22,23,33)$. We have reported earlier that human CGRP II, unlike CGRP I, inhibits pentagastrin-stimulated acid output (3).

To address other potentially different biological targets of human CGRP I and II, we have now compared the cardiovascular effects of the two CGRPs, and have reexamined the inhibition of gastric acid output. The results provide evidence that human CGRP I more potently stimulates blood flow in the skin and the common carotid artery, and plasma renin activity and aldosterone levels than CGRP II, but does not suppress gastric acid secretion.
METHOD

\section{Peptides}

Synthetic human CGRP I and II (or $\alpha$ and $\beta$ ) were purchased from Peninsula Laboratories (Belmont, CA). Over 95\% of the immunoreactive material eluted as a single peak on reversedphase HPLC (28). The CGRP was dissolved in $0.15 \mathrm{M} \mathrm{NaCl}$ containing $0.1 \%$ human serum albumin, and vials containing 6.6 $\mathrm{nmol} / \mathrm{ml}$ were prepared under aseptic conditions by the University of Basel Hospital Pharmacy and were stored at $-20^{\circ} \mathrm{C}$. The concentration of CGRP peptides obtained by weighing and by radioimmunoassay was within $10 \%$ of the predicted values.

Pentagastrin (Peptavlon) was purchased from ICI Pharma (Lucerne, Switzerland).

\section{Experimental Protocols}

Six healthy men were selected for study. Their ages ranged from 23 to 29 years and their body weights (63 to $84 \mathrm{~kg}$ ) were normal.

Blood flow, arterial pressure, heart rate, and plasma renin activity and aldosterone levels were measured before, during and after intravenous infusions of 79 or $263 \mathrm{pmol} / \mathrm{kg} / \mathrm{h}$ human CGRP I or II (25 ml/h for $60 \mathrm{~min})$ through an indwelling catheter in a forearm on four different days in random order.

Skin blood flow was studied with a laser Doppler instrument

\footnotetext{
${ }^{1}$ Requests for reprints should be addressed to Dr. J. A. Fischer, Klinik Balgrist, Forchstrasse 340, 8008 Zurich, Switzerland.
} 
(PeriFlux PF2, Perimed, Sweden) (18). The gain selector was set to $30 / 4 \mathrm{kHz}$ and the time constant to $0.2 \mathrm{~s}$. The flux values are given in arbitrary units, which correspond to $1 \mathrm{~V}$ output. The probe head was inserted in the unheated probe holder and fixed to the skin $2 \mathrm{~cm}$ below the right clavicle, in the medioclavicular line.

Blood flow through the left common carotid artery was measured using an ultrasonic duplex system (ND 256-8, Biosound, Indianapolis, IN) (18). The B-mode image of the common carotid artery was generated with an $8 \mathrm{MHz}$ transducer. Arterial diameters were measured from the B-mode (mean of 3 measurements). The transmitted frequency of the pulsed Doppler was 6.5 $\mathrm{MHz}$. The size of the sample was adjusted to the cross-sectional area of the vessel. The incident angle of the ultrasound beam with respect to the axis of the vessel was displayed on the screen. The necessary correction for calculation of absolute velocity values was automatically performed by appropriate software in the machine. The Doppler signals were analyzed by a real time spectrum analyzer (Fast Fourier Transform) providing 200 spectra per second, with a resolution of $100 \mathrm{~Hz}$. The mean velocity was determined from the velocity $(\mathrm{cm} / \mathrm{s})$ vs. time waveforms. Blood flow was computed by multiplying the cross-section by the time-averaged mean velocity.

The heart rate and the systolic and diastolic pressures were monitored every $15 \mathrm{~min}$.

Pentagastrin-stimulated gastric output was measured after an overnight fast (3). A double-lumen gastric tube was placed, under fluoroscopic guidance, into the most dependent part of the stomach. Polyethylene glycol 4000 was instilled into the stomach at a flow rate of $200 \mathrm{ml} / \mathrm{h}$, and its recovery fraction was calculated to correct for pyloric loss. Pentagastrin (390 pmol/ $\mathrm{kg} / \mathrm{h}$ ) was infused intravenously for $190 \mathrm{~min}$. Ten min after the start of the pentagastrin infusion, CGRP I or II $(79 \mathrm{pmol} / \mathrm{kg} / \mathrm{h}$ ) or $0.15 \mathrm{M} \mathrm{NaCl}$ containing $0.1 \%$ human serum albumin alone (control) were intravenously infused at $25 \mathrm{ml} / \mathrm{h}$ on three different days in random order. Gastric juice was collected in 20 -min aliquots with continuous mechanical suction. After recording the volume of the aspirate, each aliquot was analyzed for titratable acid (autotitration with $0.01 \mathrm{M} \mathrm{NaOH}$ to an end point of $\mathrm{pH}$ 7.0) and polyethylene glycol concentration (turbidimetrically).

\section{Radioimmunoassays}

Plasma renin activity and plasma levels of aldosterone and of CGRP I and II were measured by specific radioimmunoassays $(4,20,28)$ in blood samples obtained from an indwelling catheter placed in the contralateral forearm from the CGRP-infused forearm. Blood was collected into ice-chilled tubes containing lithium heparin as an anticoagulant and $5000 \mathrm{KIU}$ aprotinin (Trasylol) per $5 \mathrm{ml}$ of blood. Samples were immediately centrifuged at $4^{\circ} \mathrm{C}$ and the plasma was stored at $-20^{\circ} \mathrm{C}$ until assayed. All the samples from the same subject were determined in the same assay.

\section{Calculations and Statistical Analysis}

The metabolic clearance rate was determined using the constant infusion to equilibrium method (16).

The CGRP responses were evaluated using $t$-tests with Bonferroni's correction. The significance of differences between CGRP I and II was tested using analysis of variance followed by the nonparametric Friedman test. $p<0.05$ was considered statistically significant.

\section{RESULTS}

With $79 \mathrm{pmol} / \mathrm{kg} / \mathrm{h}$ human CGRP I, skin mean blood flow was increased up to 6-fold, between 15 and $120 \mathrm{~min}$ after the start of the infusion $(p<0.05)$, and flow through the common carotid artery was raised up to 1.5 -fold between 15 and $60 \mathrm{~min}$ after the start of the CGRP I infusions $(p<0.05)$ (Fig. 1). The raised skin blood flow responses were slightly delayed compared to the carotid blood flow. Statistically significant vasodilatation was not observed with equimolar amounts of CGRP II $(p>0.05)$. Analysis of variance revealed statistically significant differences between the action of CGRP I and II in skin blood flow, $\mathrm{F}(1,13)=6.93, p<0.02$, and in the common carotid artery, $\mathrm{F}(1,13)=8.91, p<0.02$.

The diastolic arterial pressure was lowered with $79 \mathrm{pmol} / \mathrm{kg} / \mathrm{h}$ CGRP I between 15 and $45 \mathrm{~min}$ after the start of the infusions $(p<0.05)$, but not significantly with $79 \mathrm{pmol} / \mathrm{kg} / \mathrm{h}$ CGRP II $(p>0.05)$. The difference between the actions of $79 \mathrm{pmol} / \mathrm{kg} / \mathrm{h}$ CGRP I and II was statistically significant, $\mathrm{F}(1,13)=6.55, p<0.05$. With $263 \mathrm{pmol} / \mathrm{kg} / \mathrm{h}$ CGRP I and II, similar falls of the diastolic arterial pressure were observed between 15 and $45 \mathrm{~min}$ after the start of the infusions $(p<0.05)$. The systolic arterial pressure remained unchanged (not shown). Statistically significant stimulation of the heart rate was obtained with $79 \mathrm{pmol} / \mathrm{kg} / \mathrm{h}$ CGRP I between 30 and $60 \mathrm{~min}$ after the start of the infusions, and with $263 \mathrm{pmol} / \mathrm{kg} / \mathrm{h}$ of both CGRP I and II between 15 and $60 \mathrm{~min}$ $(p<0.05)$. The stimulation was more pronounced with $263 \mathrm{pmol} /$ $\mathrm{kg} / \mathrm{h}$ CGRP I than CGRP II, F(1,13) $=11.81, p<0.01$.

Moreover, $263 \mathrm{pmol} / \mathrm{kg} / \mathrm{h}$ CGRP I stimulated plasma renin activity between 50 and $75 \mathrm{~min}$ after the start of the infusions, and, with a temporal delay between 40 and $105 \mathrm{~min}$, plasma aldosterone levels $(p<0.05)$. Unlike $79 \mathrm{pmol} / \mathrm{kg} / \mathrm{h}$ CGRP II, 79 $\mathrm{pmol} / \mathrm{kg} / \mathrm{h}$ CGRP I stimulated plasma aldosterone levels between 60 and $75 \mathrm{~min}(p<0.05)$. The increase in plasma renin activity and aldosterone levels was more pronounced with CGRP I than II, $\mathrm{F}(1,13)=9.09$ and 8.92, $p<0.01$ and $p<0.02$.

In contrast, inhibition of pentagastrin-stimulated gastric acid output was only recognized with $79 \mathrm{pmol} / \mathrm{kg} / \mathrm{h}$ CGRP II between 20 and $180 \mathrm{~min}$ after the start of the infusions $(p<0.05)$, and not with $79 \mathrm{pmol} / \mathrm{kg} / \mathrm{h}$ CGRP I, $\mathrm{F}(1,17)=20.12, p<0.01$ (Fig. 2).

Plasma levels of endogenous CGRP I and II combined prior to the administration of the CGRP were lower than $26 \mathrm{pmol} / 1$. As a result of the intravenous infusions of $263 \mathrm{pmol} / \mathrm{kg} / \mathrm{h}$ human CGRP I or II, plasma levels of CGRP I and II were $194 \pm 26$ $\mathrm{pmol} / \mathrm{l}$ and $209 \pm 38 \mathrm{pmol} / 1$, respectively. The metabolic clearance rates of CGRP I and II were $24.5 \pm 2.9 \mathrm{ml} / \mathrm{min} / \mathrm{kg}$ and $24.9 \pm 5.6 \mathrm{ml} / \mathrm{min} / \mathrm{kg}$ and were indistinguishable.

\section{DISCUSSION}

We have reported earlier that human CGRP II, unlike CGRP I, suppressed the pentagastrin-stimulated gastric acid output (3). Concerning the inhibition of gastric acid output by CGRP II, the results obtained in the present report were indistinguishable. Here the comparison between the effects of human CGRP I and II has been extended to the cardiovascular action of the neuropeptides. Enhanced blood flow in the common carotid artery, with a temporal delay in the skin, has been recognized as a sensitive action of human CGRP I in normal man $(5,18)$. In contrast to the inhibition of gastric acid secretion, CGRP II used at the same rate had no consistent effects on blood flow through the skin and the carotid artery. The fall of the diastolic arterial pressure and stimulation of the heart rate were more pronounced with CGRP I than with CGRP II. The differential action of the two CGRPs was also recognizable with the stimulation of the plasma renin activity. Renin activity was stimulated directly in the isolated rat kidney perfused at constant pressure and in isolated rat juxtaglomerular cells $(20,21)$. This effect is mediated 

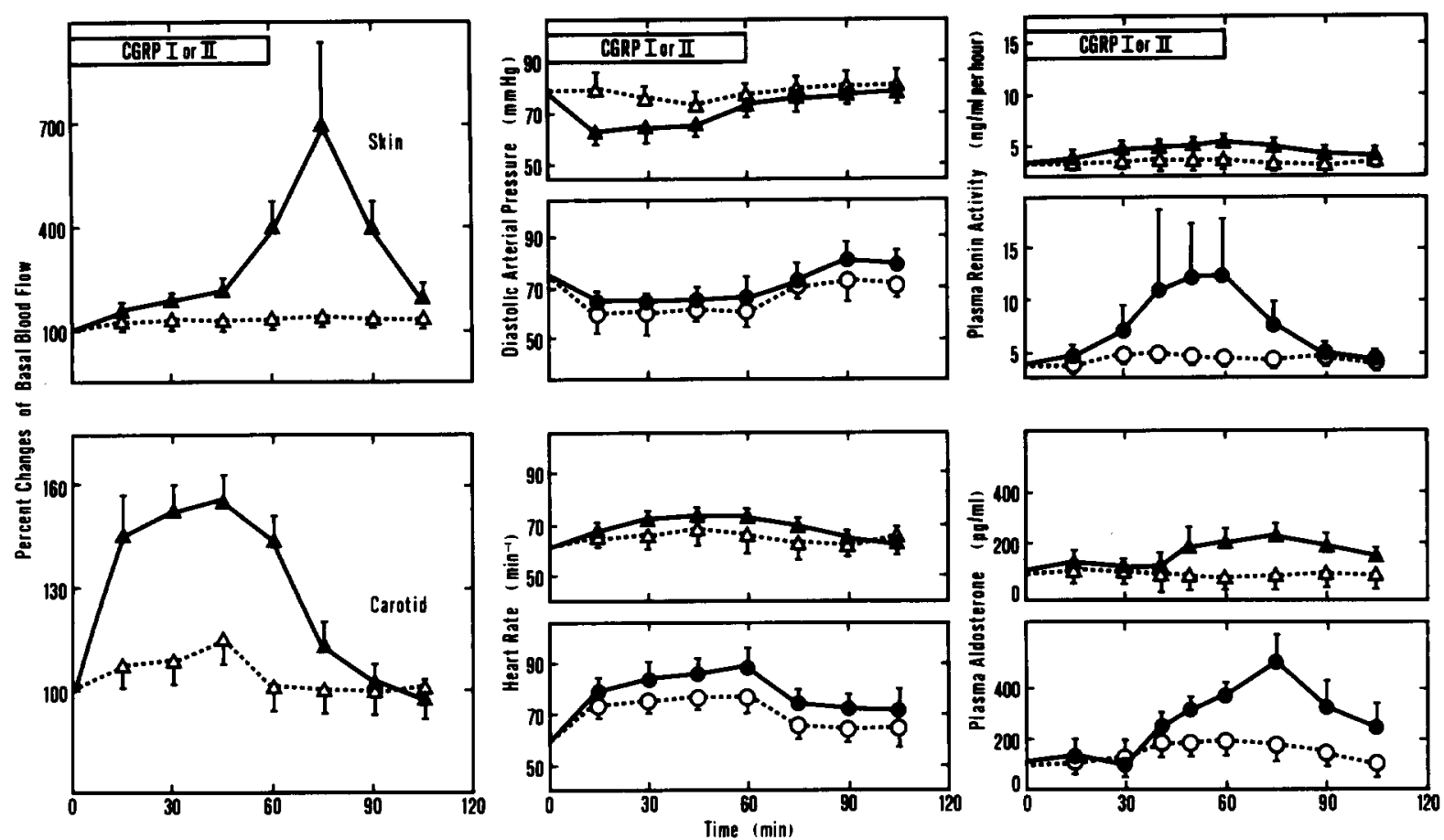

FIG. 1. Skin and carotid blood flow, heart rate, arterial pressure, plasma renin activity and aldosterone levels in response to intravenous infusions of synthetic human CGRP I (closed symbols) or II (open symbols) in 6 healthy male subjects. CGRP I or II were infused between time " 0 " and $60 \mathrm{~min}$. The $79 \mathrm{pmol} / \mathrm{kg} / \mathrm{h}$ infusions are represented by triangles and $263 \mathrm{pmol} / \mathrm{kg} / \mathrm{h}$ by circles. Data are mean values \pm SEM.

through the protein kinase A pathway (20). But renin activity is also enhanced as a result of the hypotension-evoked release of norepinephrine and epinephrine $(9-11,20,32)$. With a temporal delay and presumably as a consequence of the stimulation of renin activity, plasma levels of aldosterone were raised more dramatically with CGRP I than with CGRP II. The stimulation of aldosterone secretion by CGRP in dogs in vivo and in perfused rat adrenal glands may be caused by the lowered arterial pressure and localized vasodilatation (14). When the heart rate and arterial pressure were maintained in dogs in vivo, plasma renin activity was raised with CGRP, but plasma aldosterone levels were suppressed (27). Inhibition of aldosterone secretion was also noted in isolated rabbit glomerulosa cells (26). Overall, the renin-angiotension-aldosterone system, as counterregulatory action to the vasodilatation and hypotension, was more potently activated with CGRP I than with CGRP II.

The metabolic clearance rates of CGRP I and II, as shown here, were indistinguishable. Differences in the metabolism of CGRP I and II, therefore, do not contribute to the distinct biological effects of the two CGRPs recognized.

The existence of receptor subtypes with different affinities for CGRP I and II appears, therefore, likely. Upon cross-linking, human CGRP I(1-37) and -(8-37), and CGRP II(1-37) interact with the same apparent molecular weight $\left(M_{r} 60 \mathrm{~K}, 54 \mathrm{~K}\right.$ and $17 \mathrm{~K}$ ) binding proteins in the human cerebellum (30). On receptor autoradiography, however, subtle differences in the regional distribution of ${ }^{125}$ I-human CGRP I and II binding, e.g., in the human ventromedial hypothalamus, have been observed (13). The N-terminal fragments of human CGRP I(1-12), -(1-15), and -(1-22) lowered the arterial pressure in rats in higher amounts than the intact peptide (24). The more potent cardiovascular action of CGRP I in relation to CGRP II may be influenced by the

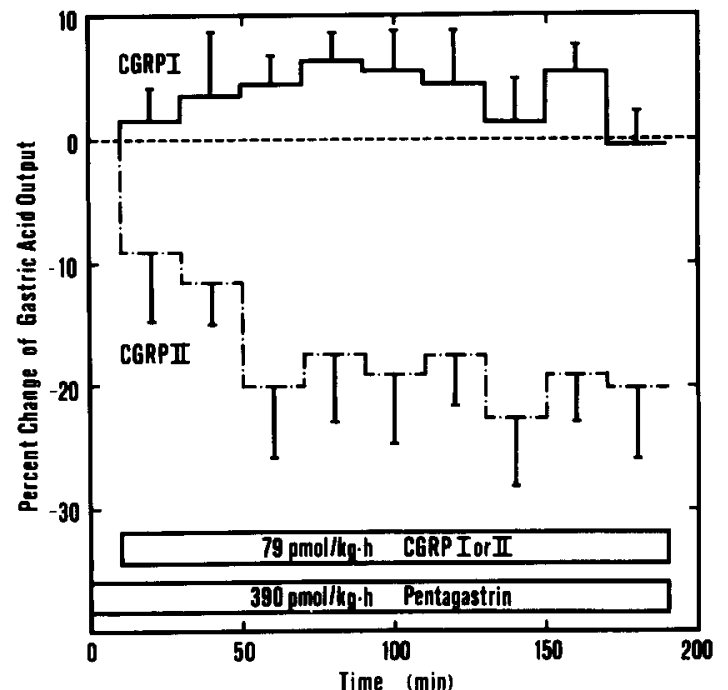

FIG. 2. Pentagastrin-stimulated gastric acid output $(\mathrm{mmol} / 15 \mathrm{~min})$ in response to human CGRP I or CGRP II in 6 healthy male subjects. Results (mean $\pm \mathrm{SEM}$ ) are expressed as changes from control experiments with pentagastrin alone. Pentagastrin-stimulated acid output before and at the end of the CGRP I infusions were: $6.2 \pm 0.4 \mathrm{mmol} / 15 \mathrm{~min}$ and $6.4 \pm 0.5 \mathrm{mmol} / 15 \mathrm{~min}$, respectively; $6.5 \pm 0.7 \mathrm{mmol} / 15 \mathrm{~min}$ and $5.2 \pm 0.5$ $\mathrm{mmol} / 15 \mathrm{~min}$ with CGRP II; and $5.9 \pm 0.6 \mathrm{mmol} / 15 \mathrm{~min}$ and $6.3 \pm 0.7$ $\mathrm{mmol} / 15 \mathrm{~min}$ in the controls. 
interaction of the negatively charged aspartate in position 3 of human CGRP I vs. the neutral asparagine in CGRP II. The C-terminal fragment human CGRP I(8-37), in contrast, caused vasoconstriction in rats (12), and antagonized positive chronotropic and ionotropic effects on the heart (7). But the antagonistic potency of CGRP I(8-37) was much weaker on the relaxation of the vas deferens of the rat (7), which is consistent with receptor heterogeneity in different target tissues $(13,29)$. Along similar lines, the linear analog [acetamidomethyl-Cys ${ }^{2,7}$ ]human CGRP I retained high potency on the relaxation of the vas deferens but lost the positive chronotropic effect on the heart (8). We speculate that the C-terminal parts of human CGRP II are important for the inhibition of gastric acid output. There the contribution of a methionine residue in position 22 in the place of a valine in human CGRP I(1-37) and a serine in the place of an asparagine in position 25 to the amphiphilic $\alpha$-helix in the C-terminal tail of human CGRP I remains to be assessed (25).

A parallel stimulation of gastric blood flow by human CGRP I and II in rabbits concomitant with increased pentagastrin-stimulated acid output with human CGRP I and inhibition with human CGRP II also points to differentiated regulatory functions of the two closely homologous neuropeptides (2).

\section{ACKNOWLEDGEMENTS}

This work was supported by the Swiss National Science Foundation Grants 3.890-0.88 and 32-28297.90, and the Kanton of Zurich.

\section{REFERENCES}

1. Amara, S. G.; Arriza, J. L.; Leff, S. E.; Swanson, L. W.; Evans, R. M.; Rosenfeld, M. G. Expression in brain of a messenger RNA encoding a novel neuropeptide homologous to calcitonin gene-related peptide. Science 229:1094-1097; 1985.

2. Bauerfeind, P.; Hof, R.; Hof, A.; Cucala, M.; Sigrist, S.; Ritter C. von; Fischer, J. A.; Blum, A. L. Effects of hCGRP I and II on gastric blood flow and acid secretion in anesthetized rabbits. Am. J. Physiol. 256:G145-G149; 1989.

3. Beglinger, C.; Born, W.; Hildebrand, P.; Ensinck, J. W.; Burkhardt, F.; Fischer, J. A.; Gyr, K. Calcitonin gene-related peptides I and II and calcitonin: Distinct effects on gastric acid secretion in humans. Gastroenterology 95:958-965; 1988.

4. Bom, W.; Beglinger, C.; Fischer, J. A. Diagnostic relevance of the amino-terminal cleavage peptide of procalcitonin (PAS-57), calcitonin and calcitonin gene-related peptide in medullary thyroid carcinoma patients. Regul. Pept. 32:311-319; 1991.

5. Brain, S. D.; Williams, T. J.; Tippins, J. R.; Morris, H. R.; MacIntyre, I. Calcitonin gene-related peptide is a potent vasodilator. Nature 313:54-56; 1985.

6. Conlon, J. M.; McGregor, G. P.; Gröndal, S.; Grimelius, L. Synthesis of $\alpha$ - and $\beta$-calcitonin gene-related peptide by a human pheochromocytoma. Peptides 10:327-331; 1989.

7. Dennis, T.; Fournier, A.; Cadieux, A.; Pomerleau, F.; Jolicoeur, F. B.; St. Pierre, S.; Quirion, R. hCGRP ${ }_{8-37}$, a calcitonin gene-related peptide antagonist revealing calcitonin gene-related peptide receptor heterogeneity in brain and periphery. J. Pharmacol. Exp. Ther. 254: $123-128 ; 1990$.

8. Dennis, T.; Fournier, A.; St. Pierre, S.; Quirion, R. Structure-activity profile of calcitonin gene-related peptide in peripheral and brain tissues. Evidence for receptor multiplicity. J. Pharmacol. Exp. Ther. 251:718-725; 1989.

9. Fisher, L. A.; Kikkawa, D. O.; Rivier, J. E.; Amara, S. G.; Evans, R. M.; Rosenfeld, M. G.; Vale, W. W.; Brown, M. R. Stimulation of noradrenergic sympathetic outflow by calcitonin gene-related peptide. Nature 305:534-536; 1983.

10. Franco-Cereceda, A.; Gennari, C.; Nami, R.; Agnusdei, D.; Pernow, J.; Lundberg, J. M.; Fischer, J. A. Cardiovascular effects of calcitonin gene-related peptides I and II in man. Circ. Res. 60:393$397 ; 1987$.

11. Gennari, C.; Fischer, J. A. Cardiovascular action of calcitonin gene-related peptide in humans. Calcif. Tissue Int. 37:581-584 1985.

12. Han, S. P.; Naes, L.; Westfall, T. C. Inhibition of periarterial nerve stimulation-induced vasodilation of the mesenteric arterial bed by CGRP (8-37) and CGRP receptor desensitization. Biochem. Biophys. Res. Commun. 168:786-791; 1990.

13. Henke, H.; Sigrist, S.; Lang, W.; Schneider, J.; Fischer, J. A Comparison of binding sites for the calcitonin gene-related peptides I and II in man. Brain Res. 410:404-408; 1987.

14. Hinson, J. P.; Vinson, G. P. Calcitonin gene-related peptide stimulates adrenocortical function in the isolated perfused rat adrenal gland in situ. Neuropeptides 16:129-133; 1990.

15. Höppener, J. W. M.; Steenbergh, P. H.; Slebos, R. J. C.; Visser, A.; Lips, C. J. M.; Jansz, H. S.; Bechet, J. M.; Lenoir, G. M.;
Born, W.; Haller-Brem, S.; Petermann, J. B.; Fischer, J. A. Expression of the second calcitonin/calcitonin gene-related peptide gene in Ewing sarcoma cell lines. J. Clin. Endocrinol. Metab. 64: 809-817; 1987.

16. Huwyler, R.; Bom, W.; Ohnhaus, E. E.; Fischer, J. A. Plasma kinetics and urinary excretion of exogenous human and salmon calcitonin in man. Am. J. Physiol. 236:E15-E19; 1979.

17. Itabashi, A.; Kashiwabara, H.; Shibuya, M.; Tanaka, K.; Masaoka, H.; Katayama, S.; Ishii, J. The interaction of calcitonin gene-related peptide with angiotensin II on blood pressure and renin release. J. Hypertens. 6(Suppl. 4):S418-S420; 1988.

18. Jäger, K.; Muench, R.; Seifert, H.; Beglinger, C.; Bollinger, A.; Fischer, J. A. Calcitonin gene-related peptide (CGRP) causes redistribution of blood flow in humans. Eur. J. Clin. Pharmacol. 39:491$494 ; 1990$.

19. Kraenzlin, M. E.; Ch'ng, J. L. C.; Mulderry, P. K.; Ghatei, M. A.; Bloom, S. R. Infusion of a novel peptide, calcitonin gene-related peptide (CGRP) in man. Pharmacokinetics and effects on gastric acid secretion and on gastrointestinal hormones. Regul. Pept. 10:189-197; 1985

20. Kurtz, A.; Muff, R.; Born, W.; Lundberg, J. M.; Millberg, B.-I.; Gnädinger, M. P.; Uehlinger, D. E.; Weidmann, P.; Hökfelt, T.; Fischer, J. A. Calcitonin gene-related peptide is a stimulator of renin secretion. J. Clin. Invest. 82:538-543; 1988.

21. Kurtz, A.; Schurek, H.-J.; Jelkmann, W.; Muff, R.; Lipp, H.-P.; Heckmann, U.; Eckhardt, K.-U.; Scholz, H.; Fischer, J. A.; Bauer, C. Renal mesangium is a target for calcitonin gene-related peptide. Kidney Int. 36:222-227; 1989.

22. Lenz, H. J.; Mortrud, M. T.; Rivier, J. E.; Brown, M. R. Calcitonin gene related peptide inhibits basal, pentagastrin, histamine, and bethanecol stimulated gastric acid secretion. Gut 26:550-555; 1985.

23. Leung, F. W.; Tallos, E. G.; Taché, Y. F.; Guth, P. H. Calcitonin gene-related peptide inhibits acid secretion without modifying blood flow. Am. J. Physiol. 252:G215-G218; 1987.

24. Maggi, C. A.; Rovero, P.; Giuliani, S.; Evangelista, S.; Regoli, D.; Meli, A. Biological activity of $\mathrm{N}$-terminal fragments of calcitonin gene-related peptide. Eur. J. Pharmacol. 179:217-219; 1990.

25. Manning, M. C. Conformation of the alpha form of human calcitonin gene-related peptide (CGRP) in aqueous solution as determined by circular dichroism spectroscopy. Biochem. Biophys. Res. Commun. 160:388-392; 1989

26. Murakami, M.; Suzuki, H.; Nakajima, S.; Nakamoto, H.; Kageyama, Y.; Saruta, T. Calcitonin gene-related peptide is an inhibitor of aldosterone secretion. Endocrinology 125:2227-2229; 1989.

27. Murakami, M.; Suzuki, H.; Nakamoto, H.; Kageyama, Y.; Naitoh, M.; Sakamaki, Y.; Saruta, T. Calcitonin gene-related peptide modulates adrenal hormones in conscious dogs. Acta Endocrinol. (Copenh.) 124:346-352; 1991

28. Petermann, J. B.; Born, W.; Chang, J.-Y.; Fischer, J. A. Identification in the human central nervous system, pituitary, and thyroid of a novel calcitonin gene-related peptide, and partial amino acid sequence in the spinal cord. J. Biol. Chem. 262:542-545; 1987.

29. Sexton, P. M.; McKenzie, J. S.; Mendelsohn, F. A. O. Evidence for a new subclass of calcitonin/calcitonin gene-related peptide bind- 
ing site in rat brain. Neurochem. Int. 12:323-335; 1988.

30. Stangl, D.; Born, W.; Fischer, J. A. Characterization and photoaffinity labeling of calcitonin gene-related peptide receptor solubilized from human cerebellum. Biochemistry 30:8605-8611; 1991.

31. Steenbergh, P. H.; Höppener, J. W. M.; Zandberg, J.; Visser, A.; Lips, C. J. M.; Jansz, H. S. Structure and expression of the human calcitonin/CGRP genes. FEBS Lett. 209:97-103; 1986.

32. Struthers, A. D.; Brown, M. J.; MacDonald, D. W. R.; Beacham, J. L.; Stevenson, J. C.; Morris, H. R.; MacIntyre, I. Human calcitonin gene related peptide: A potent endogenous vasodilator in man. Clin. Sci. 70:389-393; 1986.

33. Taché, Y.; Pappas, T.; Lauffenburger, M.; Goto, Y.; Walsh, J. H.;
Debas, H. Calcitonin gene-related peptide: Potent peripheral inhibitor of gastric acid secretion in rats and dogs. Gastroenterology 87: 344-349; 1984

34. Wimalawansa, S. J.; Morris, H. R.; Etienne, A.; Blench, I.; Panico, M.; MacIntyre, I. Isolation, purification and characterization of $\beta$-hCGRP from human spinal cord. Biochem. Biophys. Res. Commun. 167:993-1000; 1990 .

35. Wimalawansa, S. J.; Morris, H. R.; MacIntyre, I. Both $\alpha$ - and $\beta$-calcitonin gene-related peptides are present in plasma, cerebrospinal fluid and spinal cord in man. J. Mol. Endocrinol, 3:247-252; 1989. 